\title{
Systematic Literature Review (SLR) Dinamika Perencanaan Pembangunan Infrastruktur Berkelanjutan
}

\author{
Nora Eka Putri ${ }^{\circledR 1}$, Helmi $^{2}$, Melinda Noer ${ }^{2}$, Yossyafra ${ }^{2}$ \\ ${ }^{1}$ Universitas Negeri Padang, Padang, Indonesia \\ ${ }^{2}$ Universitas Andalas, Padang, Indonesia
}

\begin{tabular}{|c|c|}
\hline ARTICLE INFORMATION & A B S T R A C T \\
\hline $\begin{array}{l}\text { Received: July 08, } 2021 \\
\text { Revised: September 28, } 2021 \\
\text { Accepted: October 22, } 2021 \\
\text { Available online: October 30, } 2021\end{array}$ & \multirow{5}{*}{$\begin{array}{l}\text { This paper contributes to providing an understanding of the dynamics of infrastructure development planning in } \\
\text { sustainable development. First, this paper will explain the concept of development from the beginning. The idea is } \\
\text { used in a scientific context. Then it will also be described development planning and, in more detail about } \\
\text { infrastructure development planning. The research method used is a qualitative approach with systematic } \\
\text { literature review (SLR) from various sources of the best journals in googlescholar.com, sciencedirect.com and } \\
\text { other relevant sources. The result of this article review is to explain the development of development planning } \\
\text { conceptsfrom different periods; development planning context (Developed and Developing countries); categories } \\
\text { of physical or social infrastructure development planning; then the sustainability impact of infrastructure } \\
\text { development planning, both positive and negative effects of economic, environmental and social aspects, the last } \\
\text { about the relationship of development planning with political decision making Based on this paper it is known } \\
\text { that the dynamics of infrastructure development planning related to the sustainability of development. Then } \\
\text { development planning cannot stand autonomous as an idea or concept that is normative because political } \\
\text { decision-making determines the success of the planning. Furthermore, it is necessary to collaborate and synergize } \\
\text { development actors in realizing infrastructure development planning. The novelty in this paper is to raise some } \\
\text { research questions that can be researched for the future about the dynamics of infrastructure development } \\
\text { planning in sustainable development. }\end{array}$} \\
\hline KEYWORDS & \\
\hline Planning, Infrastructure, Decision Making & \\
\hline CORRESPONDENCE & \\
\hline $\begin{array}{l}\text { Name: Nora Eka Putri } \\
\text { E-mail: noraekaputri@fis.unp.ac.id }\end{array}$ & \\
\hline
\end{tabular}

\section{PENDAHULUAN}

Pembangunan merupakan suatu proses yang dapat meningkatkan kapasitas masyarakat secara pribadi dan kelembagaan guna memobilisasi dan mengelola sumber daya untuk keberlanjutan peningkatan kualitas hidup yang sesuai dengan aspirasi mereka (Korten, 1990). Pembangunan merupakan upaya peningkatan aspek ekonomi dan sosial yang terkait dengan pembangunan social itu sendiri (S Burkey, 1993). Selanjutnya, pembangunan terkait erat dengan aspek ekonomi dan finansial sehingga penilaian tentang pembangunan selalu dikaji dari perspektif ekonomi seperti faktor produksi, distribusi dan konsumsi individu (Edwards, 1993). Teori pembangunan juga mencerminkan perbaikan atau perubahan yang diinginkan, elemen selanjutnya adalah peran teori yang mengatur agenda, sebagai serangkaian implikasi kebijakan dan proyek masa depan (Pieterse, 2010). Pembangunan sebagai realitas fisik dan keadaan pikiran masyarakat yang memiliki beberapa kombinasi proses sosial, ekonomi, dan kelembagaan, dalam mengamankan sarana untuk mendapatkan kehidupan yang lebih baik (Todaro \& Smith, 2011). Pembangunan yaitu upaya yang sistematik dan berkesinambungan untuk menciptakan keadaan yang dapat menyediakan berbagai alternatif yang sah bagi pencapaian aspirasi setiap warga negara yang paling humanistik (Rustiadi, Saefulhakim, \& Panuju, 2018).

Dari penjelasan di atas, diketahui bahwa pembangunan bertujuan untuk mewujudkan kesejahteraan masyarakat. Terdapat tiga aspek utama tujuan pembangunan (Todaro \& Smith, 2011) antara lain: Pertama, Meningkatkan ketersediaan dan memperluas distribusi barang kebutuhan pokok seperti pangan, tempat tinggal, kesehatan, dan perlindungan. Kedua, untuk meningkatkan kehidupan, seperti pendapatan yang lebih tinggi, penyediaan lebih banyak lapangan pekerjaan, pendidikan yang lebih baik, dan perhatian yang lebih besar terhadap nilainilai budaya dan kemanusiaan, yang semuanya akan berfungsi untuk meningkatkan kesejahteraan material dan juga untuk meningkatkan harga diri individu dan nasional. Ketiga, memperluas jangkauan pilihan ekonomi dan sosial yang tersedia bagi individu dan bangsa dengan membebaskan mereka dari perbudakan dan ketergantungan, tidak hanya dalam kaitannya dengan orang lain dan negara-bangsa tetapi juga untuk kekuatan ketidaktahuan dan penderitaan manusia.

Dalam melakukan pembangunan dibutuhkan persiapan dan perencanaan yang baik. Perencanaan menurut paradigma perencanaan klasik adalah upaya terorganisasi, sadar dan terusmenerus untuk memilih alternatif terbaik yang tersedia untuk mencapai tujuan tertentu (Chimhowu, Hulme, \& Munro, 2019). Sementara konsep perencanaan dari paradigma komunikasi dan negosiasi dipandang sebagai proses komunikasi dan negosiasi tentang masa depan yang diinginkan, yang melibatkan interaksi banyak individu, melakukan tawar-menawar dan bernegosiasi dari berbagai basis daya untuk mencapai tujuan yang mencerminkan kepentingan diri mereka yang dibangun berdasarkan nilai-nilai universal (Chimhowu et al., 2019). Perencanaan pembangunan merupakan upaya rasional dalam melakukan perencanaan dengan melibatkan teknokrat yang menjadikan berbagai data sebagai sumber untuk melakukan analisis untuk melahirkan dokumen cetak biru pembangunan (Chimhowru et al., 2019). 
Perencanaan pembangunan sudah berkembang sejak dekade 1950-an sampai dengan sekarang. Beberapa pola perencanaan pembangunan telah dilakukan sejak saat itu, mulai dari perencanaan pembangunan dengan pendekatan ekonomi dan teknokrat (sampai dengan terjadi perang dingin), kemudian perencanaan pembangunan yang dipengaruhi oleh political will dan ideology suatu Negara (sampai periode kejatuhan Negara Uni Soviet), kemudian saat ini perencanaan pembangunan suatu Negara yang merujuk pada keberlanjutan pembangunan (yang dikenal dengan konsep MDGs dan SDGs). Namun meskipun perencanaan sudah dilakukan dengan baik, ternyata pelaksanaan pembangunan menimbulkan dampak negatif baik di bidang ekonomi, lingkungan maupun sosial, contohnya dampak pada pembangunan infrastruktur. Pembangunan infrastruktur menimbulkan dampak bagi kehidupan social masyarakat. Misalnya melalui proses alih fungsi tanah atau lahan yang berpindah dari masyarakat kepada pemerintah yang melakukan pembangunan, akibatnya masyarakat kehilangan tempat tinggal dan juga mata pencaharian karena pemindahan paksa (Khoshkish, 1979; Laterrasse, 2019; Meadows, Annandale, \& Ota, 2019). Kemudian persoalan lain adalah rusaknya kelestarian lingkungan dan habitat makhluk hidup yang ada di lokasi pembangunan infra struktur(Chehlafi, Kchikach, Derradji, \& Mequedade, 2019; Palomino \& Parvania, 2019; D. Sun, Zeng, Lin, Meng, \& Yu, 2019). Oleh sebab itu perlu dilakukan perencanaan pembangunan infrastruktur yang lebih baik agar dampak negatif dari pembangunan tersebut dapat diatasi.

Perencanaan pembangunan infrastruktur merupakan perencanaan dalam membangun infrastruktur baik dalam membangun jalan, saluran pembuangan, rumah sakit, sekolah dan fasilitas publik lainnya (Chang, Li, Huang, \& Wu, 2012). Selanjutnya dalam perkembangannya, perencanaan pembangunan infrastruktur dilakukan dengan beberapa pola atau konsep. Di antaranya adalah konsep green infrastructure (Chang et al., 2012), kemudian juga terdapat perencanaan pembangunan infrastruktur di Negara maju menggunakan konsep compact city(Bibri, Krogstie, \& Kärrholm, 2020). Kedua pola tersebut adalah contoh perencanaan pembangunan infrastruktur jalan. Infrastruktur jalan adalah aset utama pemerintah dan perekonomian negara di seluruh dunia (Schweikert, Chinowsky, Kwiatkowski, \& Espinet, 2014). Infrastruktur jalan mempengaruhi berbagai aspek kehidupan mulai dari perekonomian, kesejahteraan masyarakat dan juga iklim (lingkungan).

Namun dalam perkembangannya penelitian terkait perencanaan pembangunan infrastruktur jalan yang sudah dikaji dari perspektif ekonomi; komunikasi dan lingkungan membuktikan bahwa belum terlaksana dengan baik hal ini dibuktikan dengan berbagai dampak negatif yang ditimbulkan dari pembangunan tersebut, terutama yang terkait dengan dampak negatif dari aspek sosial yang berhubungan dengan masyarakat. Maka perlu diketahui dan dideskripsikan perkembangan kajian tentang perencanaan pembangunan infrastruktur berdasarkan periode waktu; kategori Negara yang melaksanakan (Negara maju atau berkembang) dan dampak keberlanjutannya. Penelitian kajian literature ini diambil dari berbagai sumber atau referensi yang relevan sehingga tujuan penelitian ini dapat mengisi gap tentang kajian perencanaan pembangunan infrastruktur dengan memasukkan aspek social dan politik.

\section{METODE}

Metode penelitian yang digunakan di dalam tulisan ini adalah pendekatan kualitatif dengan metode Systematic Literature Review (SLR) yaitu mengumpulkan artikel tentang proses dan dinamika perencanaan pembangunan dari jurnal terbaik pada berbagai sumber referensi online pada website (B. Kitchenham, Brereton, Li, Budgen, \& Burn, 2011; Barbara Kitchenham et al., 2009; Muluk, 2021), seperti www.sciencedirect.com, proquest, web of science dan juga www.google.scholar.com. Kemudian melakukan identifikasi terhadap jurnal tersebut dengan melakukan klasifikasi terhadap tema riset; metode penelitian yang digunakan; hasil riset dan juga cakupan riset (bersifat lokal, nasional atau internasional). Metode ini nantinya akan memberikan gambaran tentang dinamika perencanaan pembangunan yang harus dielaborasi dan atau dievaluasi lebih mendalam sebagai salah satu bentuk hasil review dengan mengemukakan pertanyaan penelitian untuk riset yang akan datang.

Systematic Literature Review (SLR) dilakukan berdasarkan sumber literatur; berdasarkan fokus penelitian yaitu tentang pembangunan, perencanaan pembangunan infrastruktur, dampak keberlanjutan pembangunan dari aspek ekonomi, lingkungan dan social; berdasarkan tahun terbit yaitu dari tahun 1990 sampai dengan 2021; berdasarkan metodologi yaitu metode penelitian kualitatif, metode kuantitatif, studi pustaka dan lainnya. Artikel yang memenuhi kriteria tersebut berjumlah 47 artikel.

\section{HASIL DAN PEMBAHASAN \\ Konsep Pembangunan dari Berbagai Perspektif}

Pembangunan adalah upaya berkesinambungan menciptakan keadaan yang dapat menyediakan lebih banyak alternative yang sah bagi setiap warga Negara untuk mencapai aspirasi yang paling humanistic (society welfare) (Mahi \& Trigunarso, 2017). Pembangunan diartikan suatu proses dimana anggota masyarakat meningkatkan kapasitas pribadi dan kelembagaan untuk memobilisasi dan mengelola sumber daya untuk keberlanjutan peningkatan kualitas hidup yang sesuai dengan aspirasi mereka (Korten, 1990). Teori pembangunan juga mencerminkan perbaikan atau perubahan yang diinginkan, elemen selanjutnya adalah peran teori yang mengatur agenda, sebagai serangkaian implikasi kebijakan dan proyek masa depan (Pieterse, 2010). Berikut pada tabel 1 disajikan konsep pembangunan dari berbagai perspektif.

Tabel 1. Konsep Pembangunan dari Beberapa Perspektif

\begin{tabular}{|c|c|c|}
\hline No & Perspektif & Definisi \\
\hline 1 & Ekonomi & $\begin{array}{l}\text { Pembangunan adalah upaya peningkatan } \\
\text { aspek ekonomi dan social yang terkait } \\
\text { dengan pembangunan social (Stan Burkey, } \\
\text { 1993). } \\
\text { Pembangunan terkait erat dengan aspek } \\
\text { ekonomi dan finansial sehingga penilaian } \\
\text { tentang pembangunan selalu dikaji dari } \\
\text { perspektif ekonomi seperti factor produksi, } \\
\text { distribusi dan konsumsi individu (Edwards, } \\
\text { 1993). }\end{array}$ \\
\hline 2 & Politik & $\begin{array}{l}\text { Pembangunan politik adalah perubahan } \\
\text { karakteristik system politik yang satu ke } \\
\text { system politik yang lain, misalnya perubahan } \\
\text { system politik otoriter ke system politik } \\
\text { demokratis (Adityawarman, 2020). }\end{array}$ \\
\hline
\end{tabular}




\begin{tabular}{|c|c|c|}
\hline & & $\begin{array}{l}\text { Pembangunan politik juga diartikan sebagai } \\
\text { meningkatkan perpaduan politik nasional } \\
\text { dan partisipasi politik (Dori Efendi \& Jayum } \\
\text { Jawan, 2017). Partisipasi politik yang } \\
\text { dimaksud adalah aktivitas aktor-aktor } \\
\text { politik di suatu Negara termasuk partisipasi } \\
\text { dari masyarakatnya, dari partisipasi pasif } \\
\text { menjadi partisipasi aktif dalam berbagai } \\
\text { aspek kehidupan politik (Dori Efendi \& } \\
\text { Jayum Jawan, 2017) (Umar, 2020). } \\
\text { Coleman (1958) bahwa pembangunan politik } \\
\text { adalah proses diferensiasi struktur politik } \\
\text { dari struktur politik tradisional menuju } \\
\text { struktur politik modern yang berorientasi } \\
\text { efektivitas dan efisiensi dalam kinerja } \\
\text { politiknya (Dori Efendi \& Jayum Jawan, } \\
\text { 2017). } \\
\text { ciri-ciri mendasar dari pembangunan politik } \\
\text { menurut Huntington (1965) adalah } \\
\text { rasionalisasi; integrasi; demokratisasi; } \\
\text { mobilisasi dan partisipasi (Dori Efendi \& } \\
\text { Jayum Jawan, 20l7). }\end{array}$ \\
\hline 3 & Sosial & $\begin{array}{l}\text { Pembangunan social-budaya mempunyai } \\
\text { prinsip yang tidak mudah diterima oleh } \\
\text { logika pertumbuhan kebendaan, yakni } \\
\text { adanya variable-variabel social dan } \\
\text { humaniora seperti kerukunan, kemandirian, } \\
\text { kesetiakawanan, demokrasi, kesejahteraan, } \\
\text { bahkan kebahagiaan (Wirutomo, 2013) } \\
\text { (Long, 2010) (Midlgey, 1995). Penekanan } \\
\text { pembangunan social adalah pemerataan } \\
\text { sarana dan hak-hak manusia yang paling } \\
\text { dasar (inklusi social) (Wirutomo, 2013). }\end{array}$ \\
\hline 4 & Infrastruktur & $\begin{array}{l}\text { Pembangunan infrastruktur bertujuan untuk } \\
\text { melayani kepentingan masyarakat dan } \\
\text { nantinya dapat meningkatkan kesejahteraan } \\
\text { ekonomi, peningkatan kehidupan social dan } \\
\text { menjaga kelestarian lingkungan (Kumari \& } \\
\text { Sharma, 2017). Infrastruktur di bidang } \\
\text { transportasi adalah infrastruktur yang } \\
\text { membutuhkan biaya relatif besar dan biaya } \\
\text { tersebut belum tentu menghasilkan } \\
\text { keuntungan besar dan dalam jangka waktu } \\
\text { yang singkat (Melo, Graham, \& Brage-ardao, } \\
\text { 2013) }\end{array}$ \\
\hline
\end{tabular}

Sumber: diolah peneliti dari berbagai sumber

Berdasarkan definisi pembangunan dari berbagai perspektif pada table 1 , dapat disimpulkan bahwa pembangunan adalah upaya meningkatkan kualitas hidup masyarakat dari aspek ekonomi, politik, social, lingkungan dan infrastruktur untuk pelayanan dengan melibatkan masyarakat baik dalam aspek ide, keterlibatan dalam pengambilan keputusan termasuk dalam melakukan pengawasan dari pembangunan tersebut guna terwujudnya keberlanjutan untuk kehidupan di masa mendatang.

\section{Perencanaan Pembangunan}

\section{- Perencanaan}

Perencanaan menurut paradigma perencanaan klasik adalah upaya terorganisasi, sadar dan terus-menerus untuk memilih alternatif terbaik yang tersedia untuk mencapai tujuan tertentu (Chimhowu et al., 2019). Sementara konsep perencanaan dari paradigm komunikasi dan negosiasi dipandang sebagai proses komunikasi dan negosiasi tentang masa depan yang diinginkan, yang melibatkan interaksi banyak individu yang tawarmenawar dan bernegosiasi dari berbagai basis daya untuk mencapai tujuan yang setidaknya sebagian mencerminkan kepentingan diri mereka dibangun di sekitar nilai-nilai universal (Chimhowu et al., 2019).

Perencanaan merupakan suatu proses menentukan apa yang ingin dicapai di masa yang akan datang serta menetapkan tahapan-tahapan yang dibutuhkan untuk mencapainya (Rustiadi et al., 2018). Perencanaan setidaknya mengandung dua unsur penting yaitu hal yang ingin dicapai dan cara untuk mencapainya. Hal yang ingin dicapai biasanya tertuang di dalam visi, tujuan dan sasaran, sedangkan cara untuk mewujudkan hal tersebut dilakukan melalui istilah misi, aktivitas dan lain sebagainya (Rustiadi et al., 2018).

Perencanaan yaitu kegiatan masyarakat atau lembaga untuk mengembangkan strategi yang optimal untuk mencapai serangkaian tujuan yang diinginkan (Mahi \&e Trigunarso, 2017). Perencanaan dapat dibedakan dari dua aspek. Pertama perencanaan rasional dan perencanaan berbasis proses dan consensus. Perencanaan rasional membutuhkan pengetahuan untuk membuat keputusan-keputusan yang logis dalam menelaah semua alternative yang ada. Namun tidak dipungkiri bahwa pengetahuan yang dimaksud tidak bersifat mutlak karena kapasitas pengetahuan tentang objek tertentu antara satu pihak dengan pihak lain berbeda apalagi dalam memutuskan perencanaan yang dilakukan pemerintah berakhir pada proses pengambilan keputusan politik (perencanaan berbasis proses dan consensus).

Perencanaan kontemporer tidak bisa dilepaskan dari pengambilan keputusan secara politik, sehingga perencanaan dapat dikategorikan atas "pelaku" penetapan tujuan perencanaan dan cara mencapai tujuan tersebut (Mahi \& Trigunarso, 2017):

1. Perencanaan Tradisional, bahwa perencanaan dilakukan oleh perencana (teknokratik), sebab perencana yang paling mengetahui tujuan dan cara mencapainya, hal ini dapat dilakukan karena perencana memiliki keahlian di bidang tertentu. Pendekatan ini sebagai hasil dari teori politik teknokratik yang muncul pada era revolusi industry dimana saat itu kekuatan politik dikuasai oleh golongan atas yang menguasai teknologi.

2. Perencanaan Demokratis, konsep ini muncul pada tahun 1960-an sebagai efek dari perencanaan tradisional yang dinilai top-down dan tidak memperhatikan aspirasi masyarakat dan relative tidak mewujudkan nilai demokrasi. Masyarakat dinilai memiliki hak untuk memutuskan perencanaan yang akan dilakukan pemerintah sebab masyarakat mewakili dirinya sendiri dan suara mayoritas yang nantinya menentukan perencanaan yang akan dilakukan.

3. Perencanaan Ekuiti, perencanaan ini relative sama dengan perencanaan demokratis tetapi lebih menekankan pada program-program substantive, fokusnya bergeser dari siapa yang berwenang menjadi "siapa mendapat apa". Perencanaan ekuiti memberikan kesempatan bagi sekelompok masyarakat bukan untuk masyarakat luas, jadi perencanaan ekuiti tidak selalu mempunyai pendukung mayoritas dalam masyarakat tetapi membela kelompok masyarakat tertentu (marginal, tertinggal, minoritas, tertindas). Perencanaan ekuiti ini relevan dengan pendekatan sosialis.

4. Perencanaan Inkremental, perencanaan yang dilakukan dalam jangka pendek, sepotong demi sepotong, bersambung, 
bukan dipikirkan secara jangka panjang. Potongan tindakan yang dilakukan dalam perencanaan ini didasarkan oleh kebutuhan masyarakat saat itu. Perencanaan incremental dapat dibedakan atas dua, yaitu disjointed incremental dan jointed incremental. Disjointed incremental melakukan perencanaan sepotong-sepotong tanpa memikirkan kesinambungan. Sedangkan jointed incremental memikirkan kesinambungan antar potongan-potongan akan sampai dimana nantinya.

\section{- Perencanaan Pembangunan}

Perencanaan pembangunan terkait erat dengan proses politik, pemahaman ini dikemukakan oleh Negara yang menganut paham sosialis, bahwa perencanaan pembangunan menjadi kewenangan pemerintah secara terpusat, mengikat dengan menggunakan kewenangan pemerintah dan kekuatan politik sebagai landasan utama (Warjio, 2016). Negara sosialis tidak menyerahkan sepenuhnya perencanaan pembangunan pada mekanisme pasar sebab mekanisme pasar pada akhirnya hanya menimbulkan ketidakadilan. Sehingga Negara sosialis melakukan perencanaan pembangunan untuk menghindari instabilitas ekonomi, ketidakadilan dan untuk mewujudkan kepentingan keadilan social. Perencanaan pembangunan kemudian berkembang setelah perang dunia kedua bahwa perencanaan pembangunan adalah upaya yang dilakukan oleh pemerintah mulai dari tahap perencanaan hingga pelaksanaan pembangunan untuk membangun kembali negaranya dan atau mengejar ketertinggalan pembangunan akibat perang. Khusus untuk konteks Negara berkembang perencanaan pembangunan bertujuan untuk memperbaiki mekanisme pasar yang belum berjalan sempurna; menghadapi masa depan melalui strategi perencanaan guna mengantisipasi kondisi terburuk; dan untuk memberikan arahan dan koordinasi terhadap aktor pembangunan untuk saling bersinergi (Warjio, 2016).

Perencanaan pembangunan harus bersifat partisipatif dan melibatkan masyarakat, sebab perencanaan pembangunan dipengaruhi oleh kepercayaan dari masyarakat (Lubis, 2009). Masyarakat sebagai bagian terbesar dalam system demokrasi adalah aspek yang sangat penting dalam perumusan kebijakan termasuk di dalam perencanaan pembangunan. Selama ini peran serta masyarakat dalam perencanaan pembangunan belum optimal sehingga sering ditemui bahwa pembangunan yang dilakukan oleh pemerintah berbenturan dengan kepentingan dan aspirasi masyarakat. Oleh sebab itu perlu dilibatkan masyarakat secara partisipatif di dalam perencanaan pembangunan. Peran aktif masyarakat dalam perencanaan pembangunan tidak terlepas dari tujuan untuk mewujudkan transparansi dalam pengambilan kebijakan publik untuk pelaksanaan pembangunan. Terdapat factor-factor yang terkait dengan partisipasi dan transparansi dalam perencanaan pembangunan di Negara yang menganut system demokrasi, antara lain: public trust, legitimacy, accountability, public service dan public disobedience (Lubis, 2009).

Selanjutnya perencanaan pembangunan juga harus memperhatikan impact chain (mata rantai) dari pembangunan yang akan dilakukan. Pemerintah harus melakukan analisis dampak mata rantai yang dimulai dari input; output hingga outcome (Muktiali, 2009). Input adalah ketersediaan dan kesiapan sumber daya mulai dari pembiayaan (APBN/ APBD/ swasta/ masyarakat) hingga SDM yang akan melaksanakan pembangunan. Sedangkan output adalah sesuatu yang diharapkan berhasil dicapai baik berupa kebijakan, program atau target pembangunan fisik. Selanjutnya outcome adalah yang mencerminkan berfungsi sebagai hasil dari kegiatan seperti ukuran kinerja dari suatu program.

Jadi secara umum dapat dijelaskan bahwa perencanaan pembangunan adalah upaya sistematis yang dipilih sebagai alternative terbaik untuk keberlanjutan peningkatan kualitas hidup masyarakat di bidang ekonomi, social dan lingkungan yang bersifat rasional, terukur dengan melibatkan partisipasi masyarakat dalam menetapkan kebijakan pembangunan.

\section{Perencanaan Pembangunan Infrastruktur}

\section{- Perencanaan Pembangunan Infrastruktur}

Perencanaan pembangunan infrastruktur merupakan bagian dari perencanaan pembangunan wilayah. Pembangunan infrastruktur menjadi salah satu parameter pelaksanaan pembangunan wilayah (Sukwika, 2018). Perencanaan pembangunan infrastruktur adalah perencanaan dalam membangun infrastruktur baik dalam membangun jalan, saluran pembuangan, rumah sakit, sekolah dan fasilitas publik lainnya (Chang et al., 2012). Selanjutnya dalam

Perkembangannya, perencanaan pembangunan infrastruktur dilakukan dengan beberapa pola atau konsep. Di antaranya adalah konsep green infrastructure, yaitu konsep yang mengutamakan perhatian terhadap keberlangsungan hidup suatu bangsa secara alami dengan menjaga kelestarian alam dan habitat satwa dan juga mempertahankan sumber udara dan air yang bersih dan berkontribusi pada kualitas hidup masyarakat (Chang et al., 2012). Kemudian juga terdapat perencanaan pembangunan infrastruktur di Negara maju menggunakan konsep compact city, yaitu paradigm urbanisme dengan memanfaatkan semua potensi infrastruktur seperti pemanfaatan lahan campuran; transportasi berkelanjutan dan penggunaan ruang terbuka hijau sebagai kunci keberlanjutan pembangunan pada aspek ekonomi, lingkungan dan social (Bibri et al., 2020).

Di antara perkembangan topik penelitian tentang perencanaan pembangunan infrastruktur adalah perencanaan pembangunan infrastruktur yang memperhatikan kelestarian lingkungan; pembangunan infrastruktur pertanian; public private partnership (PPP); smart city; perencanaan kota dan aspek lain tentang perencanaan pembangunan infrastruktur. Terkait dengan tulisan ini kajian yang akan dibahas adalah tentang perencanaan pembangunan infrastruktur fisik (jalan). Berikut pada gambar 1 Perkembangan Penelitian Peremcamaan Pembangunan Infrastruktur.

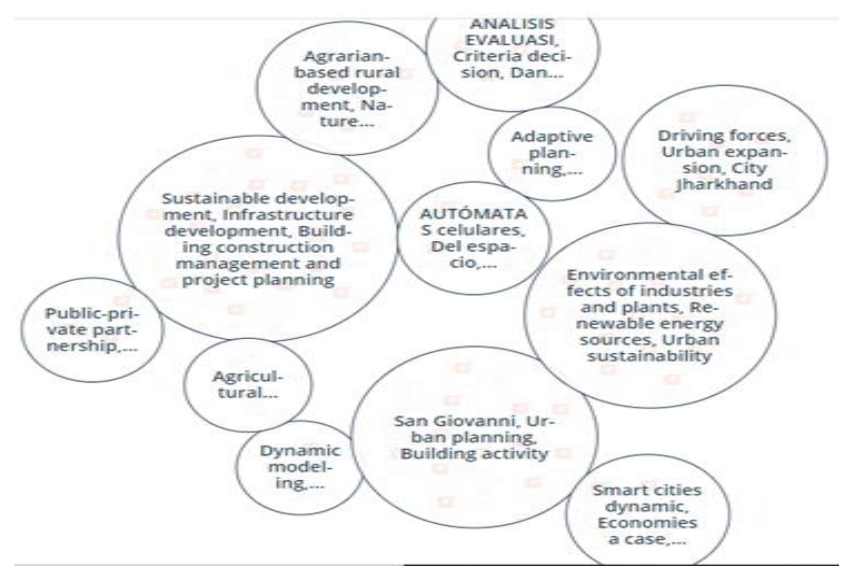

Gambar 1. Perkembangan Topik Penelitian tentang

Perencanaan Pembangunan Infrastruktur Tahun 2000 s.d 2021 Sumber: www.knowledgemap.com di akses 8 Januari 2021 
- Perencanaan Pembangunan Infrastruktur di Negara Maju dan Negara Berkembang

Perencanaan pembangunan infrastruktur di Negara maju dengan Negara berkembang relative berbeda. Kecenderungan perencanaan pembangunan infrastruktur di Negara maju telah memikirkan dampak terhadap multi aspek seperti aspek ekonomi, lingkungan dan social (Gaddefors, Korsgaard, \& Bruun, 2019). Hal ini bertujuan untuk mewujudkan keberlanjutan secara menyeluruh. Kemudian sumber daya yang ada di Negara maju juga mendukung perencanaan pembangunan yang mendukung semua aspek. Sementara di Negara berkembang perencanaan pembangunan infrastruktur terfokus pada keberlanjutan salah satu aspek saja misal ekonomi atau lingkungan. Lebih lanjut sedikit ditemui kajian tentang perencanaan pembangunan infrastruktur di Negara berkembang yang memperhatikan aspek social untuk mendukung keberlanjutan. Berikut pada tabel 2 tentang perkembangan perencanaan pembangunan infrastruktur di Negara maju dan Negara berkembang.

Tabel 2. Perbandingan Perencanaan Pembangunan Infrastruktur di Negara Maju dan Negara Berkembang

\begin{tabular}{|c|c|c|c|c|c|}
\hline \multirow{2}{*}{\multicolumn{2}{|c|}{ Negara }} & \multirow{2}{*}{ Infrastruktur } & \multicolumn{3}{|c|}{ Dampak Keberlanjutan } \\
\hline & & & Ekonomi & Lingkungan & Sosial \\
\hline \multirow[t]{2}{*}{ Negara Maju } & Belanda & Jalan & $\sqrt{ }$ & $\checkmark$ & $\sqrt{ }$ \\
\hline & Swedia & $\begin{array}{l}\text { Konsep compact city (synergy } \\
\text { semua aspek infrastruktur) }\end{array}$ & $\sqrt{ }$ & $\checkmark$ & $\checkmark$ \\
\hline \multirow{3}{*}{$\begin{array}{l}\text { Negara } \\
\text { Berkembang }\end{array}$} & India & Sistem transportasi perkotaan & $\checkmark$ & & \\
\hline & China & $\begin{array}{l}\text { Konsep Green Infrastructure dalam } \\
\text { pembangunan jalan, fasilitas publik }\end{array}$ & & $\sqrt{ }$ & \\
\hline & $\begin{array}{l}\text { Negara di } \\
\text { Afrika }\end{array}$ & $\begin{array}{l}\text { Infrastruktur Teknologi dan } \\
\text { Komunikasi (ICT) }\end{array}$ & $\checkmark$ & & \\
\hline
\end{tabular}

Sumber: Data diolah Peneliti data bersumber dari tahun 2010-2021

Dari data tabel 2 diketahui bahwa perencanaan pembangunan infrastruktur di Negara maju sudah memperhatikan dampak keberlanjutan social, sementara di Negara berkembang belum mengkaji dampak keberlanjutan social. Hal ini relatif sama dengan hasil penelitian tentang perencanaan pembangunan infrastruktur di Negara berkembang yang terbit pada artikel-artikel ilmiah sebelumnya. Diantara aspek yang mempengaruhi kondisi tersebut adalah dalam pengambilan keputusan untuk kebijakan pembangunan infrastruktur di Negara berkembang relative belum maksimal dibandingkan di Negara maju dalam melibatkan partisipasi masyarakat. Padahal kajian tersebut dapat memberikan kontribusi bagi stakeholder untuk merumuskan kebijakan dan standar penilaian terhadap risiko dan potensi manfaat dari pembangunan infrastruktur fisik tersebut.

\section{Dinamika Perencanaan Pembangunan Infrastruktur}

Dinamika perencanaan pembangunan infrastruktur dapat dikaji dari berbagai aspek seperti aspek ekonomi, lingkungan dan social. Dinamika perencanaan pembangunan memberikan gambaran tentang proses pembangunan yang memberikan dampak positif maupun negative pada aspek tertentu. Dinamika perencanaan pembangunan jika ditinjau dari aspek ekonomi adalah perencanaan yang berorientasi pada keuntungan atau profit namun tidak berarti juga bahwa perencanaan pembangunan membutuhkan biaya tinggi. Begitu juga dengan perencanaan pembangunan dari aspek lingkungan dan social. Berikut ini akan dijelaskan dampak perencanaan pembangunan dari berbagai aspek.

\section{- Dampak Ekonomi}

Dampak pembangunan infrastruktur dari aspek ekonomi dapat dilihat secara positif dan negative. Dampak positif yaitu memberikan kontribusi untuk peningkatan kualitas ekonomi masyarakat, sementara dampak negative dari pembangunan terhadap aspek ekonomi adalah kondisi ekonomi masyarakat menjadi lebih buruk dibandingkan pembangunan infrastruktur dilakukan. Berikut ini adalah dampak positif dari pembangunan infrastruktur:

1. Pembangunan infrastruktur dapat meningkatkan pendapatan domestic bruto (PDB) suatu wilayah, sehingga ini juga akan meningkatkan pendapatan fiscal pemerintah. Hal ini terjadi pada pembangunan infrastruktur transportasi publik yang dikelola dengan baik(Y. Sun \& Cui, 2018)

2. Pembangunan infrastruktur yang dikondisikan dengan baik dapat menarik investasi dengan mengurangi biaya kemudian juga memberikan peluang bagi pengembangan industry pariwisata seperti infrastruktur transportasi umum perkotaan (Y. Sun \& Cui, 2018)

3. Memberikan kesempatan kepada masyarakat terdampak untuk membuka peluang usaha baik di bidang kuliner maupun kontribusi dalam pengelolaan kelompok sadar wisata (Glasson, 2017)

Berbeda halnya jika pembangunan infrastruktur tidak dikelola dengan baik, maka akan memberikan dampak negative. Pembiayaan pemeliharaan yang tinggi tidak berkorelasi positif dengan peningkatan pendapatan masyarakat (Kumari \& Sharma, 2017; Mun, 2019; Rabello Quadros \& Nassi, 2015; Suseno, Wibowo, \& Setiadji, 2015). Kemudian investasi atas pembangunan infrastruktur membutuhkan waktu relative lama untuk pengembaliannya sebab pembangunan infrastruktur terutama infrastruktur untuk kepentingan publik membutuhkan perbaikan dan pemeliharaan (Berawi, Zagloel, Miraj, \& Mulyanto, 2017; Melo et al., 2013; Musso et al., 2013; Rabello Quadros \&e Nassi, 2015; Short \& Kopp, 2005). Selanjutnya pembangunan infrastruktur memiliki risiko dalam keadaan darurat seperti terjadinya bencana alam (Fisch-Romito \& Guivarch, 2019). Pembangunan infrastruktur juga menyebabkan risiko kemiskinan bagi masyarakat di sekitar pembangunan infrastruktur seperti pembangunan jalan tol yang dapat membuat kondisi masyarakat setempat menjadi lebih buruk secara ekonomi (Eguavoen \& Tesfai, 2012). Kemudian risiko lain adalah masyarakat dirugikan secara ekonomi atas pemindahan secara 
paksa lokasi lahan ganti rugi sebab akan mengubah pola mata pencaharian masyarakat seperti di lokasi awal sebelum pembangunan infrastruktur dilakukan (Cernea, 2000; Vanclay, 2017).

\section{- Dampak Lingkungan}

Selain dampak ekonomi, pembangunan infrastruktur juga memberikan pengaruh terhadap lingkungan. Dampak positif dari pembangunan infrastruktur dapat mengurangi emisi karbon dan gas rumah kaca, hal ini terjadi pada pembangunan infrastruktur transportasi umum perkotaan yang dikelola dengan baik (Y. Sun \& Cui, 2018). Sistem infrastruktur transportasi umum perkotaan yang sangat baik (umumnya di Negara maju) bermanfaat untuk mempromosikan penduduk perkotaan untuk memilih-nya sebagai moda perjalanan utama dan mengurangi penggunaan transportasi pribadi. Ini mengurangi emisi polusi dan gas berbahaya yang kondusif untuk meningkatkan kualitas udara perkotaan (Y. Sun \& Cui, 2018). Penurunan penggunaan transportasi pribadi sangat membantu untuk mengurangi munculnya kebisingan lalu lintas yang melindungi kehidupan perkotaan dan lingkungan kerja (Y. Sun \& Cui, 2018).

Sementara efek negative bagi lingkungan atas pembangunan infrastruktur adalah terjadinya pencemaran lingkungan. Potensi terjadi polusi udara, polusi air dan bencana alam juga menjadi salah satu efek negatif yang harus dihadapi dalam proyek pembangunan infrastruktur, contohnya asap kendaraan bermotor dapat merusak kualitas udara dan ini berpengaruh kepada kesehatan masyarakat; pembangunan infrastruktur jalan dapat merusak kawasan hutan yang nantinya menimbulkan banjir, tanah longsor dan sebagainya (Palomino \& Parvania, 2019; D. Sun et al., 2019). Kemudian juga terjadi kerusakan pada struktur tanah yang pada akhirnya membuat pemanfaatan infrastruktur seperti jalan tol menjadi kurang optimal (Chehlafi et al., 2019; Sjafruddin, 2011).

\section{- Dampak Sosial}

Pembangunan infrastruktur juga memberikan manfaat secara social. Misalnya pembangunan infrastruktur transportasi umum perkotaan yang dikelola dengan baik dapat mengembangkan industri transportasi guna mempromosikan pengembangan industri terkait lainnya melalui interaksi antara industri yang berbeda (Y. Sun \& Cui, 2018). Kemudian pengembangan berbagai macam industri bermanfaat untuk membuka lapangan pekerjaan baru dan mengurangi pengangguran di perkotaan. Kenaikan permintaan tenaga kerja menaikkan tingkat upah orang yang dipekerjakan yang sangat membantu untuk menambah pendapatan perkotaan. Selanjutnya infrastruktur transportasi umum perkotaan memberikan kemudahan untuk memperluas wilayah perkotaan dan aliran populasi yang mengakibatkan imigrasi penduduk dari daerah pedesaan. Hal ini menguntungkan untuk menaikkan tingkat urbanisasi satu kota (Y. Sun \& Cui, 2018). Infrastruktur transportasi umum perkotaan berdampak pada kesehatan penduduk perkotaan; dan tingkat pendaftaran siswa yang memiliki pengaruh penting pada kemajuan social (Y. Sun $\&$ Cui, 2018).

Sementara itu pembangunan infrastruktur juga menimbulkan permasalahan social bagi masyarakat. Pembangunan infrastruktur jalan tol dapat mengubah pola interaksi social masyarakat, terjadi disartikulasi komunitas social yang dapat membahayakan struktur social budaya masyarakat yang terdampak pembangunan infrastruktur, kebiasaan hidup yang dilakukan masyarakat cenderung hilang termasuk juga resiko kehilangan pekerjaan dan mata pencaharian (Cernea, 2004; Eguavoen \& Tesfai, 2012).

\section{Hubungan Perencanaan Pembangunan dengan Pengambilan Keputusan Politik}

Perencanaan pembangunan di suatu Negara berhubungan dengan pengambilan keputusan secara politik, sebab perencanaan pembangunan dilakukan sebagai hasil kebijakan publik yang dilahirkan dalam proses pengambilan secara politik. Meskipun perencanaan pembangunan sudah disusun secara rasional dan dengan pendekatan ilmiah, peran politik tetap ada di dalam mewujudkan perencanaan pembangunan tersebut.

Peran politik yang dimaksud adalah proses pengambilan keputusan yang melibat aktor-aktor kebijakan termasuk masyarakat. Aktor-aktor kebijakan tersebut merumuskan perencanaan pembangunan dengan bermacam pertimbangan dan tujuan tertentu sehingga memang proses politik pada akhirnya yang menentukan seperti apa perencanaan pembangunan dilakukan termasuk perencanaan pembangunan infrastruktur.

Di antara model pengambilan keputusan dalam kebijakan publik dapat dijelaskan lebih lanjut di dalam tulisan berikutnya (Anggara, 2014) antara lain: Pertama, model rasional bertujuan untuk memaksimalkan keuntungan sosial bagi masyarakatmengutamakan efisiensi. Kedua, model incremental yaitu variasi dari model kebijakan sebelumnya yang pernah adadiistilahkan juga dengan kebijakan "tambal sulam", karena kebijakan sebelumnya tetap dipakai jika masih relevan dan ditambah variasi program atau kebijakan yang sesuai dengan konteks terkini. Ketiga, model Garbage Can, yaitu model gabungan seperti ini memberikan ruang yang lebih luas untuk inovasi daripada model inkremental tanpa dibebani dengan tuntutan yang tidak realistis dari model rasional. Keempat, model komprehensif, yaitu model yang menggali dari akar masalah sampai dengan implementasi kebijakan. Kelima, model kepuasan, model ini menggunakan pendekatan pembentukan kebijakan dari dimensi perilaku, memberikan tekanan pada aspek-aspek sosio- psikologis dalam pembuatan keputusan organisasi. Keenam, model mixed scanning, model pengamatan campuran, yakni suatu model terhadap pembuatan keputusan yang memperhitungkan keputusan-keputusan pokok dan inkremental, menetapkan proses-proses pembuatan kebijakan pokok dan urutan tinggi yang menentukan petunjuk- petunjuk dasar, proses mempersiapkan keputusan pokok dan menjalankan. Ketujuh, model sistem, model ini disusun hanya dari sudut pandang para pembuat kebijakan. Dalam hal ini, para pembuat kebijakan dilihat perannya dalam perencanaan dan pengoordinasian untuk menemukan pemecahan masalah yang akan menghitung kesempatan dan meraih atau menggunakan dukungan internal dan eksternal, memuaskan permintaan lingkungan, dan secara khusus memuaskan keinginan atau kepentingan para pembuat kebijakan.

Keputusan atau kebijakan publik pembangunan infrastruktur jalan bertujuan untuk efisiensi; orientasi ekonomi; keselamatan jalan; lingkungan; infrastruktur dan struktur perkotaan (Visser, Binsbergen, \& Nemoto, 1999). Namun belum banyak ditemui kajian tentang keputusan kebijakan publik di bidang infrastruktur termasuk jalan yang 
bertujuan untuk keberlanjutan sosial masyarakat (Visser et al., 1999), sehingga seringkali menimbulkan permasalahan di masa depan. Kecenderungan siklus hidup kebijakan pada proses pengambilan keputusan kebijakan publik dilakukan secara top down dan bottom up (Lebeau, Macharis, Mierlo, \& Janjevic, 2018; Visser et al., 1999). Pengambilan keputusan secara top down cenderung didasari atas keputusan pemerintah, karena mereka memiliki sumber daya (kekuasaan, dana dan kekuatan (Rustiadi et al., 2018). Sementara pengambilan keputusan secara bottom up juga melibatkan pihak lain seperti swasta (Visser et al., 1999) dan juga partisipasi masyarakat (Lebeau et al., 2018), sebab infrastruktur jalan adalah suatu kebutuhan masyarakat, dan diasumsikan masyarakat yang paling memahami kebutuhannya sehingga pendekatan bottom up dinilai lebih inovatif dan dapat mengurangi perbedaan antara aktor kebijakan (legislative dan eksekutif) (Arundel, Bloch, \& Ferguson, 2019).

Pengambilan keputusan melalui proses kombinasi top down dan bottom up menurut Hjern dan Hull dapat diimplementasikan melalui beberapa langkah (Rustiadi et al., 2018) yaitu pertama, mengidentifikasi jaringan stakeholders (aktor-aktor yang ada); kedua, memahami tujuan, strategi, kegiatan dan hubungan-hubungan antar aktor yang ada; ketiga, berdasarkan informasi yang diperoleh kemudian dibangun kesepahaman dan kesepakatan baik di tingkat lokal, regional maupun nasional termasuk antara pemerintah, swasta, ahli dan masyarakat.

Berikut ini adalah alur pengambilan keputusan politik atas perencanaan pembangunan yang dilakukan oleh pemerintah. Proses pengambilan keputusan kombinasi antara top down dan bottom up dinilai lebih relevan dilakukan untuk melahirkan kebijakan perencanaan pembangunan, sebab proses ini melibatkan semua stakeholders termasuk masyarakat. Salah satu penyebab proses pengambilan keputusan yang bersifat top down relative bermasalah disebabkan karena masyarakat tidak dilibatkan pada awal perencanaan pembangunan, tetapi hanya ketika sosialisasi kebijakan sehingga relative terjadi permasalahan di tengah masyarakat. Maka dengan menambahkan proses bottom up menjadi alternative sebagai proses pengambilan keputusan perencanaan pembangunan infrastruktur yang dapat memberikan analisis tentang risiko dan analisis potensi manfaat terkait pembangunan infrastruktur terutama pada aspek social yang berhubungan langsung dengan masyarakat. Berikut pada Gambar 2. Disajikan tentang alur pengambilan keputusan secara kombinasi

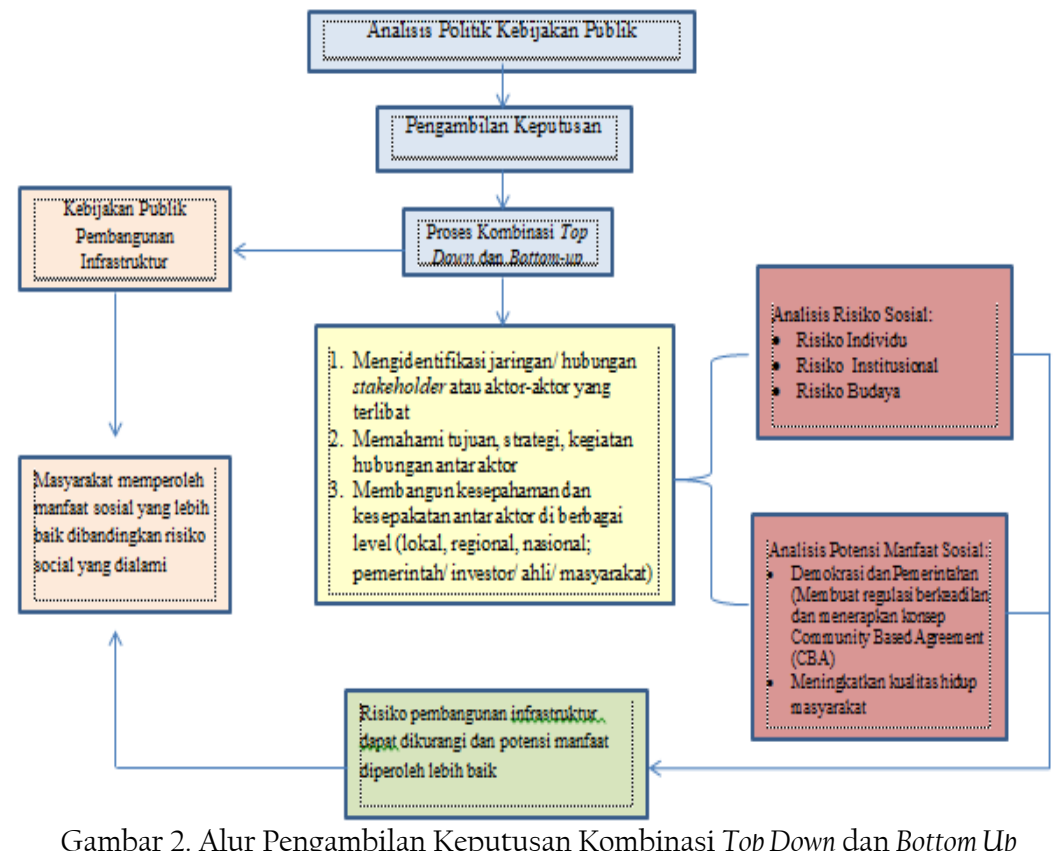

Gambar 2. Alur Pengambilan Keputusan Kombinasi Top Down dan Bottom Up untuk Perencanaan Pembangunan Infrastruktur

Sumber: Rustiadi, 2018

Dari gambar 2 dapat dipahami bahwa dengan menambahkan proses pengambilan keputusan politik secara bottom up dapat mengakomodasi semua kepentingan stakeholder dalam melahirkan perencanaan pembangunan sebab sudah ada kesepahaman dan kesepakatan terkait dengan penilaian terhadap analisis risiko dan potensi manfaat social atas pembangunan infrastruktur.

Selama ini perencanaan pembangunan infrastruktur relative terfokus pada aspek ekonomi, teknis dan lingkungan. Padahal pembangunan infrastruktur bertujuan untuk mensejahterakan masyarakat (S Burkey, 1993), akan tetapi pembangunan justru menimbulkan dampak negative bagi masyarakat. Hal ini terjadi karena perencanaan pembangunan infrastruktur relative sedikit mengkaji dan menganalisis dari aspek social. Sehingga dampak negative aspek social dari pembangunan infrastruktur bermunculan dan menimbulkan masalah baru di tengah masyarakat. Masalah tersebut antara lain adalah kebijakan pengadaan tanah, pemindahan paksa (displacement) masyarakat terdampak pembangunan infrastruktur; risiko kemiskinan (impoverishment risk) seperti kehilangan tanah, kehilangan pekerjaan, kehilangan pelayanan kesehatan dan pendidikan dan lain sebagainya.

Selanjutnya akan dikemukakan kebaruan dari tulisan ini yaitu pertanyaan penelitian untuk masa akan datang yang relevan dengan dinamika perencanaan pembangunan dari aspek social, seperti pada tabel 3. berikut ini: 
Tabel 3. Pertanyaan Penelitian Masa yang Akan Datang

\begin{tabular}{|c|c|c|c|}
\hline No & Fokus Kajian & $\begin{array}{c}\text { Pertanyaan } \\
\text { Penelitian yang } \\
\text { Akan Datang }\end{array}$ & $\begin{array}{c}\text { Pengembangan } \\
\text { dari Tulisan } \\
\text { Penulis }\end{array}$ \\
\hline 1 & $\begin{array}{l}\text { Kebijakan } \\
\text { dalam } \\
\text { Perencanaan } \\
\text { Pembangunan }\end{array}$ & $\begin{array}{l}\text { Bagaimana analisis } \\
\text { risiko social } \\
\text { terhadap kebijakan } \\
\text { perencanaan } \\
\text { pembangunan } \\
\text { infrastruktur? }\end{array}$ & $\begin{array}{l}\text { F. Vanclay } \\
\text { (Vanclay, 2017) }\end{array}$ \\
\hline 2 & $\begin{array}{l}\text { Kelembagaan } \\
\text { dalam } \\
\text { Perencanaan } \\
\text { Pembangunan }\end{array}$ & $\begin{array}{l}\text { Bagaimana } \\
\text { pelaksanaan } \\
\text { collaborative planning } \\
\text { dalam } \\
\text { pembangunan } \\
\text { infrastruktur } \\
\text { keberlanjutan? }\end{array}$ & $\begin{array}{l}\text { I. Eguavoen and } \\
\text { W. Tesfai } \\
\text { (Eguavoen \&e } \\
\text { Tesfai, 2012) }\end{array}$ \\
\hline
\end{tabular}

\section{KESIMPULAN}

Dari kajian literature yang dilakukan tentang dinamika perencanaan pembangunan infrastruktur dapat disimpulkan bahwa perencanaan pembangunan infrastruktur antara negara maju dengan Negara berkembang memiliki karakteristik yang cukup berbeda. Kecenderungan perencanaan pembangunan infrastruktur di Negara maju telah memperhatikan semua aspek keberlanjutan (ekonomi; lingkungan; social). Sementara di Negara berkembang belum memperhatikan semua aspek, tetapi salah satu aspek atau du aspek keberlanjutan saja. Selanjutnya dari ketiga aspek keberlanjutan tersebut perhatian dan kajian terhadap keberlanjutan aspek social di Negara berkembang relative lebih sedikit dibandingkan dengan dua aspek lain, terutama yang terkait dengan keterlibatan atau partisipasi masyarakat terdampak pembangunan infrastruktur dalam pengambilan keputusan perencanaan pembangunan.

Hasil dari review literature ini adalah mengemukakan kebaruan berupa pertanyaan penelitian untuk masa yang akan datang yang terkait dengan perencanaan pembangunan infrastruktur yang bertitik tolak dari konteks dampak keberlanjutan aspek social, sebab kajian mengenai ini yang relative sedikit dilakukan oleh peneliti sebelumnya terutama di Negara berkembang.

\section{UCAPAN TERIMA KASIH}

Ucapan terimakasih penulis sampaikan kepada Promotor dan Co-promotor yang sudah memberikan saran dan masukan dalam penyelesaian artikel ini. Kemudian ucapan terimakasih juga disampaikan kepada semua pihak yang tidak dapat disebutkan satu persatu yang sudah membantu baik secara moril maupun secara materil dalam penyelesaian artikel ini.

\section{REFERENSI}

Adityawarman. (2020). Pembangunan politik dan kualitas demokrasi. Jurnal Moderat, 6(2), 397-409.

Anggara, S. (2014). Kebijakan Publik. Bandung: Pustaka Setia.

Arundel, A., Bloch, C., \& Ferguson, B. (2019). Advancing innovation in the public sector: Aligning innovation measurement with policy goals. Research Policy, 48(3), 789798. https://doi.org/10.1016/j.respol.2018.12.001

Berawi, M. A., Zagloel, T. Y., Miraj, P., \& Mulyanto, H. (2017).
Producing Alternative Concept for the Trans-sumatera Toll Road Project Development using Location Quotient Method. Procedia Engineering, 171, 265-273. https://doi.org/10.1016/j.proeng.2017.01.334

Bibri, S. E., Krogstie, J., \& Kärrholm, M. (2020). Compact City Planning and Development: Emerging Practices and Strategies for Achieving the Goals of Sustainable Development. Developments in the Built Environment, 4(March), 100021. https://doi.org/10.1016/j.dibe.2020.100021

Burkey, Stan. (1993). People first: a guide to self-reliant participatory rural development. Retrieved from https:/www.cabdirect.org/cabdirect/abstract/1993180334 6

Cernea, M. M. (2000). Impoverishment Risks, Risk Management, and Reconstruction: A Model of Population Displacement and Resettlement. 1-61. Conference Preceedings, Washington.

Cernea, M. M. (2004). Social Impacts and Social Risks in Hydropower Programs: Preemptive Planning and Counter-risk Measures. 22. Conference Proceedings, Beijing.

Chang, Q., Li, X., Huang, X., \& Wu, J. (2012). A GIS-based Green Infrastructure Planning for Sustainable Urban Land Use and Spatial Development. Procedia Environmental Sciences, 12(41001112), 491-498. https://doi.org/10.1016/j.proenv.2012.01.308

Chehlafi, A., Kchikach, A., Derradji, A., \& Mequedade, N. (2019). Highway cutting slopes with high rainfall erosion in Morocco: Evaluation of soil losses and erosion control using concrete arches. Engineering Geology, 260(June), 105200. https://doi.org/10.1016/j.enggeo.2019.105200

Chimhowu, A. O., Hulme, D., \& Munro, L. T. (2019). The 'New' national development planning and global development goals: Processes and partnerships. World Development, 120, 76-89. https://doi.org/10.1016/j.worlddev.2019.03.013

Dori Efendi, \& Jayum Jawan. (2017). Pembangunan Politik Dan Pendemokrasian: Suatu Analisis Konseptual. Journal of Social Sciences and Humanities, 12(3), 1-13.

Edwards, E. A. (1993). Development of a New Scale for Measuring Compulsive Buying Behavior. Financial Counseling and Planning, 4(313), 67-85.

Eguavoen, I., \& Tesfai, W. (2012). Social impact and impoverishment risks of the Koga irrigation scheme, Blue Nile basin, Ethiopia. Afrika Focus, 25(1), 39-60. https://doi.org/10.21825/af.v25il.4962

Fisch-Romito, V., \& Guivarch, C. (2019). Transportation infrastructures in a low carbon world: An evaluation of investment needs and their determinants. Transportation Research Part D: Transport and Environment, 72. https://doi.org/10.1016/j.trd.2019.04.014

Gaddefors, J., Korsgaard, S., \& Bruun, M. (2019). Regional development through entrepreneurial exaptation: Epistemological displacement, affordances, and collective agency in rural regions. Journal of Rural Studies, (October), 113. https://doi.org/10.1016/j.jrurstud.2019.10.010

Glasson, J. (2017). Large Energy Projects and Community Benefits Agreements - Some experience from the UK. Environmental Impact Assessment Review, 65(March), 12-20. https://doi.org/10.1016/j.eiar.2017.03.009

Khoshkish, A. (1979). The Socio-political Complex (lst ed.). New York: Pergamon Press. 
Kitchenham, B., Brereton, P., Li, Z., Budgen, D., \& Burn, A. (2011). Repeatability of systematic literature reviews. IET Seminar Digest, 2011(1), 46-55. https://doi.org/10.1049/ic.2011.0006

Kitchenham, Barbara, Pearl Brereton, O., Budgen, D., Turner, M., Bailey, J., \& Linkman, S. (2009). Systematic literature reviews in software engineering - A systematic literature review. Information and Software Technology, 51(1), 7-15. https://doi.org/10.1016/j.infsof.2008.09.009

Korten, D. C. (1990). Getting to the 21st Century: Voluntary Action and the Global Agenda.

Kumari, A., \& Sharma, A. K. (2017). Infrastructure financing and development: A bibliometric review. International Journal of Critical Infrastructure Protection, 16, 49-65. https://doi.org/10.1016/j.ijcip.2016.11.005

Laterrasse, J. (2019). Transport and Town Planning, The City in Search of Sustainable Development. London: ISTE.

Lebeau, P., Macharis, C., Mierlo, J. Van, \& Janjevic, M. (2018). Improving Policy Support in City Logistics: The Contributions of A Multi-Actor Multi-Criteria Analysis. Case Studies on Transport Policy, 6(4), 554-563. https://doi.org/10.1016/j.cstp.2018.07.003

Long, N. (2010). Building a Conceptual and Interpretative Framework. In Development Sociology. https://doi.org/10.4324/9780203398531_chapter_3

Lubis, A. (2009). Upaya meningkatkan partisipasi masyarakat dalam pembangunan. Jurnal Tabularasa PPS UNIMED, 6(2), 181-190

Mahi, A. K., \& Trigunarso, S. I. (2017). Perencanaan Pembangunan Daerah Teori dan Aplikasi (1st ed.). Depok: Kencana.

Meadows, J., Annandale, M., \& Ota, L. (2019). Indigenous Peoples' participation in sustainability standards for extractives. Land Use Policy, 88(July), 104118. https://doi.org/10.1016/j.landusepol.2019.104118

Melo, P. C., Graham, D. J., \& Brage-ardao, R. (2013). The productivity of transport infrastructure investment: A meta-analysis of empirical evidence. Regional Science and Urban Economics, 43(5), 695-706. https://doi.org/10.1016/j.regsciurbeco.2013.05.002

Midlgey, J. (1995). Social Development: The Developmental Perspective in Social Welfare. In Social Development: The Developmental Perspective in Social Welfare (lst ed.). https://doi.org/10.4135/9781446221839

Muktiali, M. (2009). 1. pendahuluan. Repository Universitas Diponegoro, 1-15.

Muluk, M. R. K. (2021). Systematic Literature Review On Asymmetric Decentralization. BISNIS \& BIROKRASI: Jurnal Ilmu Administrasi Dan Organisasi, 28(2). https://doi.org/10.20476/jbb.v28i2.1036

Mun, S. il. (2019). Joint provision of transportation infrastructure. Economics of Transportation, (April 2018), 100118. https://doi.org/10.1016/j.ecotra.2019.06.001

Musso, A., Piccioni, C., Tozzi, M., Godard, G., Lapeyre, A., \& Papandreou, K. (2013). Road Transport Elasticity: How Fuel Price Changes can Affect Traffic Demand on a Toll Motorway. Procedia - Social and Behavioral Sciences, 87, 85-102. https://doi.org/10.1016/j.sbspro.2013.10.596

Palomino, A., \& Parvania, M. (2019). Advanced charging infrastructure for enabling electrified transportation.
Electricity Journal, 32(4), 21-26. https://doi.org/10.1016/j.tej.2019.03.003

Pieterse, J. N. (2010). Development Theory, Second Edition. California: SAGE.

Rabello Quadros, S. G., \& Nassi, C. D. (2015). An evaluation on the criteria to prioritize transportation infrastructure investments in Brazil. Transport Policy, 40, 8-16. https://doi.org/10.1016/j.tranpol.2015.02.002

Rustiadi, E., Saefulhakim, S., \& Panuju, D. R. (2018). Perencanaan dan Pengembangan Wilayah (A. E. Pravitasari, ed.). Jakarta: Yayasan Pustaka Obor Indonesia.

Schweikert, A., Chinowsky, P., Kwiatkowski, K., \& Espinet, X. (2014). The infrastructure planning support system: Analyzing the impact of climate change on road infrastructure and development. Transport Policy, 35, 146153. https://doi.org/10.1016/j.tranpol.2014.05.019

Short, J., \& Kopp, A. (2005). Transport infrastructure: Investment and planning. Policy and research aspects *. Transport Policy, $\quad 12, \quad 360-367$. https://doi.org/10.1016/j.tranpol.2005.04.003

Sjafruddin, A. (2011). Pembangunan Infrastruktur Transportasi untuk Menunjang Pembangunan Berkelanjutan Berbasis Ilmu Pengetahuan. $1-11$.

Sukwika, T. (2018). Peran Pembangunan Infrastruktur terhadap Ketimpangan Ekonomi Antarwilayah di Indonesia. Jurnal Wilayah Dan Lingkungan, 6, 115-130. https://doi.org/10.14710/jwl.6.2.115-130.

Sun, D., Zeng, S., Lin, H., Meng, X., \& Yu, B. (2019). Can transportation infrastructure pave a green way? A city-level examination in China. Journal of Cleaner Production, 226, 669678. https://doi.org/10.1016/j.jclepro.2019.04.124

Sun, Y., \& Cui, Y. (2018). Evaluating the coordinated development of economic, social and environmental bene fi ts of urban public transportation infrastructure: Case study of four Chinese autonomous municipalities. Transport Policy, (January), 1-11. https://doi.org/10.1016/j.tranpol.2018.02.006

Suseno, Y. H., Wibowo, M. A., \& Setiadji, B. H. (2015). Risk analysis of BOT scheme on post-construction toll road. Procedia Engineering, 125, 117-123. https://doi.org/10.1016/j.proeng.2015.11.018

Todaro, M., \& Smith, S. C. (2011). Economic Development, llth Edition. In S. Yagan (Ed.), Economic Development (1lth ed.). Boston: Pearson.

Umar, H. (2020). Pembangunan Politik dan Teoritis. Jurnal Ilmu Dan Budaya, khusus, 8257-8274.

Vanclay, F. (2017). Project-induced displacement and resettlement: from impoverishment risks to an opportunity for development? Impact Assessment and Project Appraisal, 35(1), 3-21. https://doi.org/10.1080/14615517.2017.1278671

Visser, J., Binsbergen, A. van, \& Nemoto, T. (1999). Urban freight transport policy and planning. First International Symposium on CityLogistics, (July). Cairns, Australia.

Warjio. (2016). Politik Pembangunan (Paradoks, Teori, Aktor, dan Ideologi).

Wirutomo, P. (2013). Mencari Makna Pembangunan Sosial: Studi Kasus Sektor Informal di Kota Solo. MASYARAKAT: Jurnal Sosiologi, $\quad$ 18(1), 101-120. https://doi.org/10.7454/mjs.vl8il.3735 